
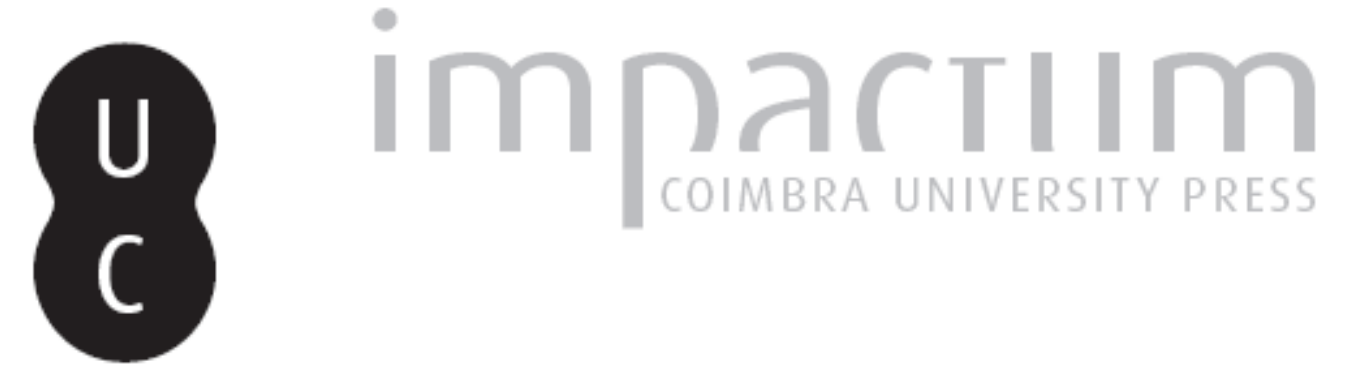

The Portuguese Economy: the challenge of low growth and high debt

Autor(es): $\quad$ Araújo, Isabel; Lourenço, Diogo; Pereira, Francisco Nunes

Publicado por: Centro de Informação Europe Direct de Aveiro; Centro de Estudos

URL

persistente:

Interdisciplinares do Século XX; Imprensa da Universidade de Coimbra

DOI: $\quad$ DOI:https://doi.org/10.14195/1647-6336_15-1_6

Accessed : $\quad$ 26-Apr-2023 07:54:54

A navegação consulta e descarregamento dos títulos inseridos nas Bibliotecas Digitais UC Digitalis, UC Pombalina e UC Impactum, pressupõem a aceitação plena e sem reservas dos Termos e Condições de Uso destas Bibliotecas Digitais, disponíveis em https://digitalis.uc.pt/pt-pt/termos.

Conforme exposto nos referidos Termos e Condições de Uso, o descarregamento de títulos de acesso restrito requer uma licença válida de autorização devendo o utilizador aceder ao(s) documento(s) a partir de um endereço de IP da instituição detentora da supramencionada licença.

Ao utilizador é apenas permitido o descarregamento para uso pessoal, pelo que o emprego do(s) título(s) descarregado(s) para outro fim, designadamente comercial, carece de autorização do respetivo autor ou editor da obra.

Na medida em que todas as obras da UC Digitalis se encontram protegidas pelo Código do Direito de Autor e Direitos Conexos e demais legislação aplicável, toda a cópia, parcial ou total, deste documento, nos casos em que é legalmente admitida, deverá conter ou fazer-se acompanhar por este aviso. 
DEBATER

A EUROPA

Supplementum

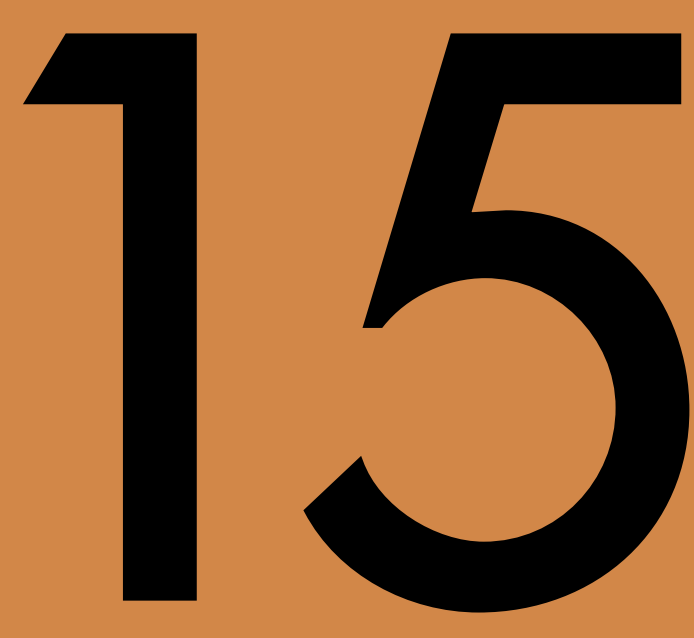

jul-dez 2016

GLOBAL TRENDS 2030:

THE FUTURES OF PORTUGAL

IN AND BEYOND EUROPE 


\section{The Portuguese Economy: the challenge of low growth and high debt}

Isabel Araújo

PhD Student

Faculty of Economics, University of Porto

Polytechnic Institute of Cávado and Ave

E-mail: isabelsilvaaraujo@ hotmail.com

Diogo Lourenço, PhD

Centre for Research in Higher Education Policies;

Faculty of Economics, University of Porto

E-mail: dlourenco@fep.up.pt

Francisco Nunes Pereira

PhD Student

Faculty of Economics, University of Porto

E-mail: franciscolfnp@gmail.com

\section{Introduction}

In the report entitled Global Trends 2030 - citizens in an interconnected and polycentric world, edited by Álvaro Vasconcelos, three mega-trends were identified for the evolution of global society until 2030: the empowerment of individuals, greater human development with rising inequality, climate change and scarcity of natural resources, and, finally, the emergence of a polycentric world with concomitant regulatory challenges.

According to the report, these three mega-trends operate through concrete manifestations, some of which are economic in nature. Thus, the empowerment of individuals operates, in part, by a global expansion of the middle classes. However, this 
expansion, as well as the expected increase in human development, are to be accompanied by increased inequality and persistent pockets of poverty. Regarding the more developed countries, the report draws attention to the potentially long-lasting negative effects of the 2008 crisis on quality of life, poverty, outward migratory flows and brain drain. Finally, the report notices the increasing impact of environmental destruction and, especially, of climate change and scarcity of natural resources.

During the nine sessions of the conference cycle Global Trends 2030: the futures for Portugal, held at Serralves Foundation between September 2015 and February 2016, José Manuel da Fonseca Moura also noticed the profound technological transformations affecting present consumption and production, in what he termed "the fourth industrial revolution". Renato Janine, on the other hand, mentioned that the secret for a sustainable democracy is in the economy, namely in its ability to sustain the aspirations of the population. Finally, Carlos Lopes challenged us to pay attention to Africa, and to its noteworthy recent development and growth, which are expected to last for decades. On June 29, 2016, a seminar was held to discuss the reports of a group of experts inspired by the several conferences. Then, Fernando Alexandre reminded us of the challenges of high external debt to the Portuguese economy, whereas Luísa Schmidt brought to the fore the untapped potential of endogenous resources, and the great sectorial transformations currently affecting the Portuguese economy.

The present article takes these contributions as a point of departure for reflecting on the opportunities and challenges facing the Portuguese economy in the next fifteen years. To this end, we will first make a brief note on the economic growth that is expected to characterize the Portuguese economy until 2030, and how it compares with that of other European countries. Afterwards, we identify and discuss a few topics we believe will take centre stage in the Portuguese public space during the next few years, viz. public accounts, external debt, unemployment, low levels of education and skills, dependency on foreign sources of energy and the challenge of climate change. We also discuss a few trends in the fields of education and inequality.

\section{Economic growth until 2030}

The divergence of the Portuguese economy from that of its counterparts is not a recent phenomenon. Indeed, on the brink of modern economic growth, in the early decades of the nineteenth century, income or gross domestic product (GDP) per capita 
of the Portuguese economy hovered around $60 \%$ of that of the most prominent economies of North and Central Europe (Table 1). This difference widened over the nineteenth and early twentieth centuries, as the Portuguese economy grew more slowly than that of its counterparts, and it stagnated in the 1930s at a level of income per capita of just over one third of that of those economies. The Portuguese economy began converging with Central and Northern Europe in the 1950s, and by 1973 income per capita in Portugal was, again, back to about $60 \%$ of that of Central and Northern Europe. Until the late 1990s, the Portuguese economy boasted higher growth rates than that of its counterparts, and by the year 2000 per capita income in Portugal had converged to about $70 \%$ of those countries' average. Since then, however, the growth of income per capita in Portugal has been slower than that of Central and Northern Europe, thus diverging from that of the latter. In 2010, it was only $65 \%$ of their average.

Table 1: Ratio of Portuguese GDP per capita with that of a selection of countries. Source: Maddison Project

\begin{tabular}{|c|c|c|}
\hline & $\begin{array}{c}\text { Northern and Central } \\
\text { European countries }\end{array}$ & Leading Economy \\
\hline $\mathbf{1 8 2 0}$ & $60.4 \%$ & $44.5 \%$ \\
\hline $\mathbf{1 9 1 4}$ & $36.2 \%$ & $25.5 \%$ \\
\hline $\mathbf{1 9 3 0}$ & $36.0 \%$ & $25.3 \%$ \\
\hline $\mathbf{1 9 4 5}$ & $43.7 \%$ & $15.4 \%$ \\
\hline $\mathbf{1 9 5 0}$ & $42.2 \%$ & $21.8 \%$ \\
\hline $\mathbf{1 9 7 3}$ & $58.5 \%$ & $42.3 \%$ \\
\hline $\mathbf{1 9 8 0}$ & $57.6 \%$ & $43.3 \%$ \\
\hline $\mathbf{1 9 9 0}$ & $64.5 \%$ & $46.7 \%$ \\
\hline $\mathbf{2 0 0 0}$ & $69.2 \%$ & $48.5 \%$ \\
\hline $\mathbf{2 0 0 5}$ & $66.4 \%$ & $46.0 \%$ \\
\hline $\mathbf{2 0 1 0}$ & $65.5 \%$ & $46.8 \%$ \\
\hline 1 & & \\
\hline & Austria, Belgium, Denmark, Finland, France, Germany, centre and north of \\
Italy, Netherlands, Norway, Sweden, Switzerland, United Kingdom \\
\hline${ }^{2}$ Until 1914: United Kingdom. Since 1914: United States of America. \\
\hline
\end{tabular}

After the crisis that has beset the Portuguese economy in recent years, economic growth is now seen as a "matter of urgency" ${ }^{1}$. However, even according to the most optimistic forecasts, growth rates in the coming years are likely to be inferior to those observed after Portugal joined the European Economic Community. Generally, projections for the next decade and a half point to a moderate growth of the Portuguese economy. According to the Organization for Economic Co-operation and Development (OECD), Portuguese GDP per capita is expected to grow around $1.4 \%$ per year in real

\footnotetext{
${ }^{1}$ IMF - Country Report 13/19
} 
terms. This organization thus projects for Portugal one of the lowest rates of the European Union (EU), and below the projected average for the OECD economy as a whole, which should grow at about $1.7 \%$ per year. Thus, the process of divergence of Portugal from its counterparts, in action since the beginning of the century, is likely to continue operating until at least 2030.

\section{The State and Public Accounts}

Since the Carnation Revolution, the Portuguese State has deepened its welfare functions. This has caused a significant growth in the value created by the Portuguese State with the provision of healthcare or educational services, for example, and in the value of transfers to pensioners and welfare recipients. This increase has been significant not only in absolute terms, but also as a share of GDP (Figure 1).

Figure 1: Public expenditure as \% of GDP on a selection of headings. Source: Pordata

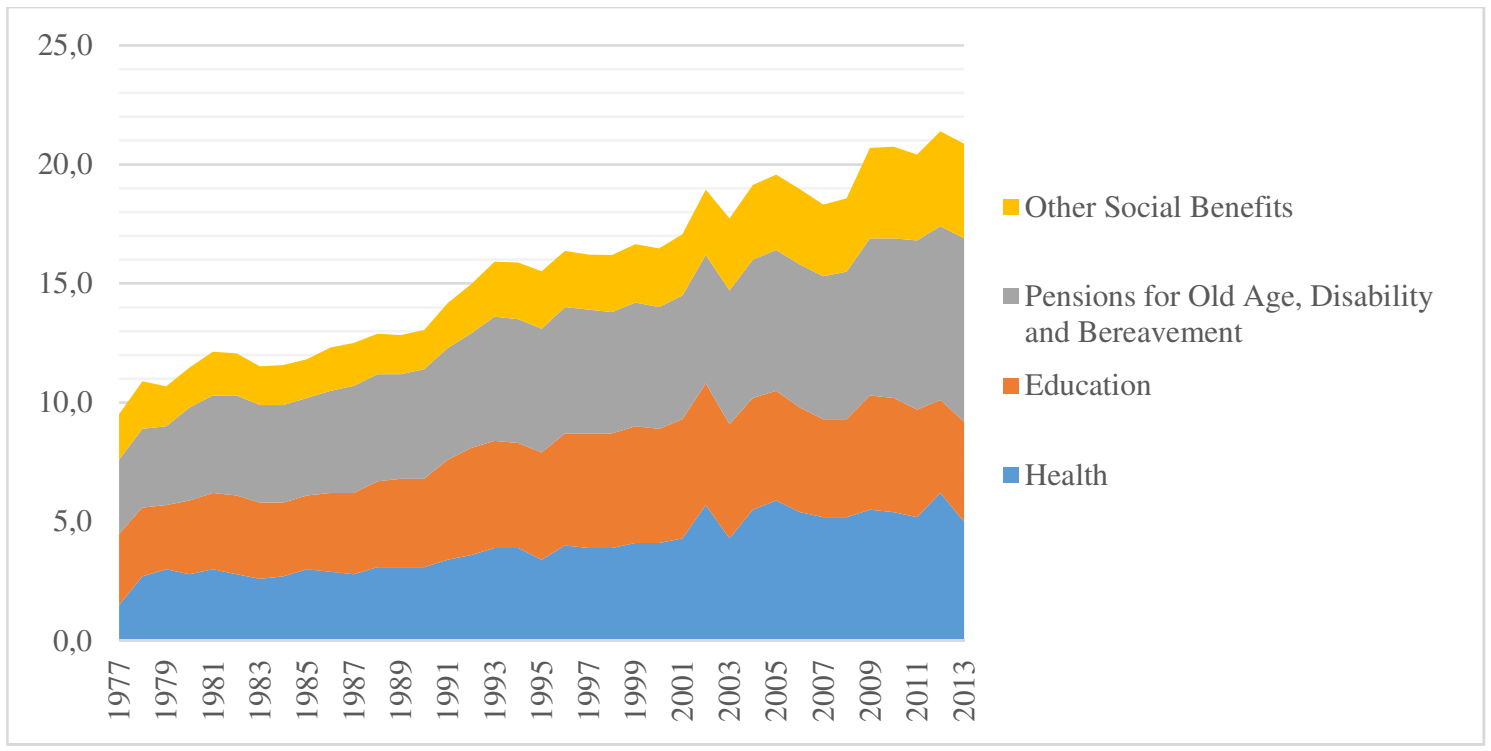

Recent demographic trends for Portugal are leading to a smaller, more aged, population. The ageing of the Portuguese population will be accompanied by a decline in the share of the labour force in total population. At the same time, forecasts project GDP per capita to grow until 2030, which indicates that the increase in productivity of the employed population will more than compensate for the reduction in the proportion of workers. Thus, the challenges to the Portuguese Welfare System, inevitably caused by an ageing population, are not a matter of income, but of choices regarding the transfer of income from the employed to the retired population. Whatever collective 
choices are made, it seems likely that the weight of pension transfers will increase in the coming decades.

Expenditure on healthcare and educational services has been stable in recent years (Figure 1). However, changes to the age structure of the population indicate that there might be an increase in healthcare expenditures in the medium-term. This might be offset by a reduction in public spending on education, due to the reduction in the number of school-age people. However, as discussed below, Portugal suffers from lowlevels of formal education, so any reduction in the number of school-age people might be offset by an increase in the proportion of such people who receive some sort of education or training.

As the Portuguese State increased its spending, there has arisen a chronic deficit in public accounts. Indeed, since 1975, Portugal has only recorded fiscal deficits of less than 3\% of GDP in 6 years, all post-1996, and is undergoing since 2009 an Excessive Deficit Procedure, as contemplated in the Stability and Growth Pact. The difficulties in controlling deficit spending should remain in the coming years.

Finally, as far as public debt is concerned, its value exceeded the threshold of $60 \%$ of GDP in the early 2000s. Following the 2008 crisis, there was an upsurge in this indicator, which surpassed 100\% in 2011 and reached a peak of around 130\% in 2014 (Figure 2). A debt of this order of magnitude raises challenges that will greatly limit the possibilities of intervention by the Portuguese State in coming years.

Figure 2: Public debt as\% of GDP. Source: Pordata

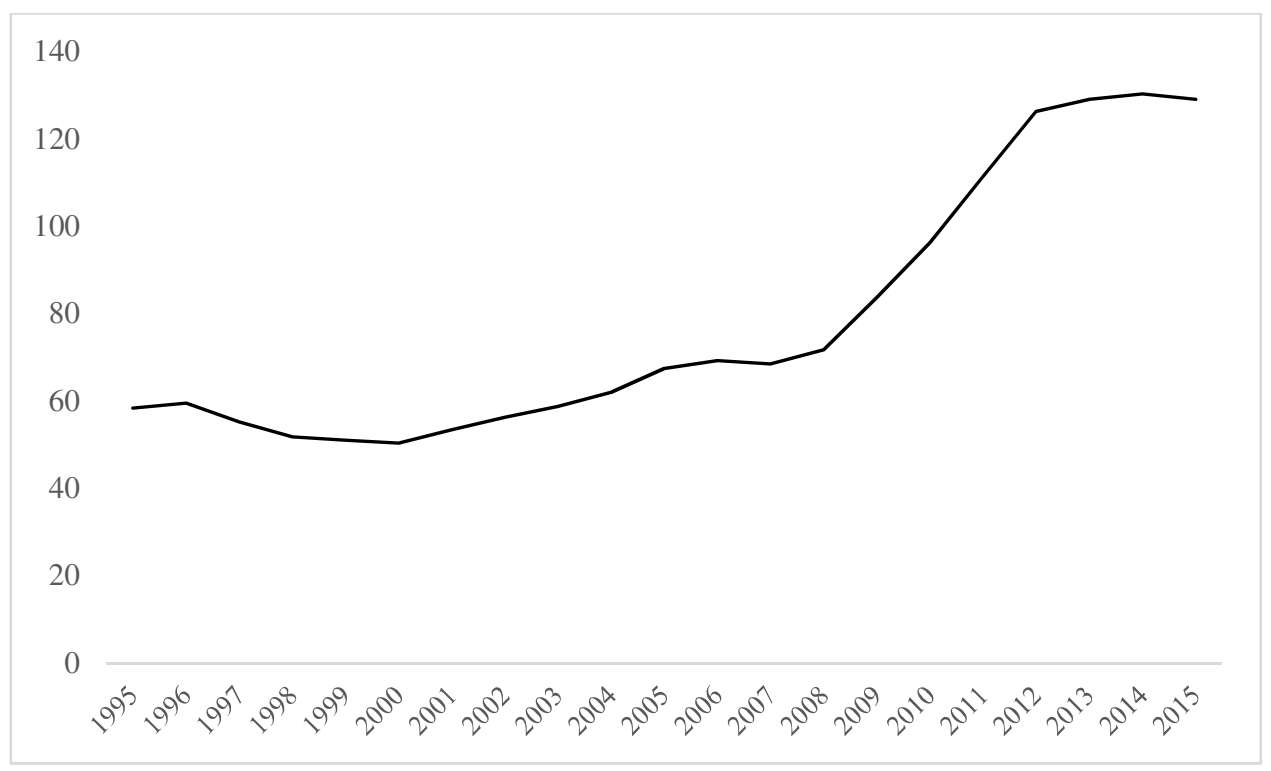




\section{External Debt}

Any discussion of public debt should be followed by a reflection on external debt, i.e. debt to non-domestic creditors.

Since the beginning of this century, Portuguese (net) external debt has grown from around one-fifth of GDP to values that surpass it (Figure 3). External debt grows, roughly, when domestic output is not enough for the consumption and public and private investment of residents. If external financing is an efficient way for the economy to finance the investment needed for its development, high debt exposes the national economy to funding crises and to the burden of high interest rates.

The recent growth in Portuguese public debt results both from growth in public debt and from the growth in household and corporate indebtedness. The reduction in private savings, in turn, is the result of easy access to credit, and of the widening of the State's welfare function, which reduces traditional incentives to saving ${ }^{2}$.

Figure 3: Portuguese net external debt as\% of GDP (current prices). Source: Pordata

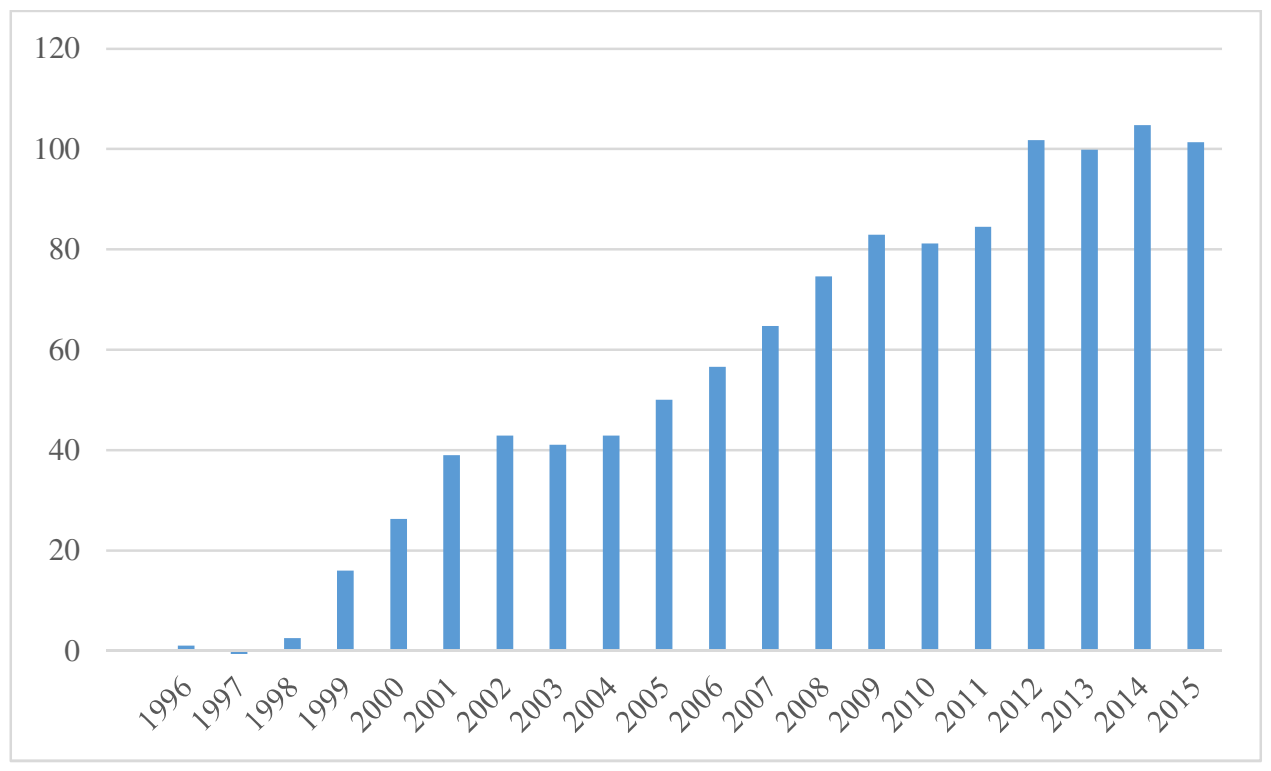

Current levels of external debt can only be met with an increase in domestic savings. This requires not only a reduction in public deficit spending and debt, but also a reduction in corporate and household indebtedness.

\footnotetext{
${ }^{2}$ ALEXANDRE, F., AGUIAR-CONRARIA, L., \& BAÇÃO, P. - Crise e Castigo: os Desequilíbrios e o Resgate da Economia Portuguesa, p. 74
} 


\section{Labour Market: Unemployment and Skills}

\section{Unemployment}

In addition to the personal and social suffering that accompanies unemployment, it also has a significant, negative economic impact. A high unemployment rate is not only a waste of productive resources, but an obstacle to economic growth, as being in a state of unemployment contributes to stagnation or even loss of workers' skills. In fact, some skills can only be developed by doing, and are lost if not constantly stimulated. In addition, lack of occupation, especially if affecting the young, boosts emigration, thus diminishing, in the medium-term, the resources of the economy and its possibilities of production and growth. Young Portuguese who are not employed, in education or training $^{3}$, correspond to about $11 \%$ of the Portuguese population between the ages of 15 and 24, a value that has remained stable since 2005 but which was, in 2015, the 13th highest of the European Union ${ }^{4}$.

The provisional estimate for the unemployment rate for the second quarter of 2016 stood at $11 \%$ of the working population. Since 2013 there has been a decline in unemployment, but its order of magnitude is still higher than in the pre-crisis period. According to the IMF, the Portuguese unemployment rate is expected to remain above $10 \%$ by 2020 . A large share of unemployment in Portugal is long-term unemployment, i.e. a large share of the unemployed have been looking for work for at least 12 months (Figure 4).

\footnotetext{
3 "NEET": "not in employment, education or training".

${ }^{4}$ With 28 countries. Source: EUROSTAT
} 
Figure 4: Rate of unemployment (orange) and of long-term unemployment (blue). Source: INE.

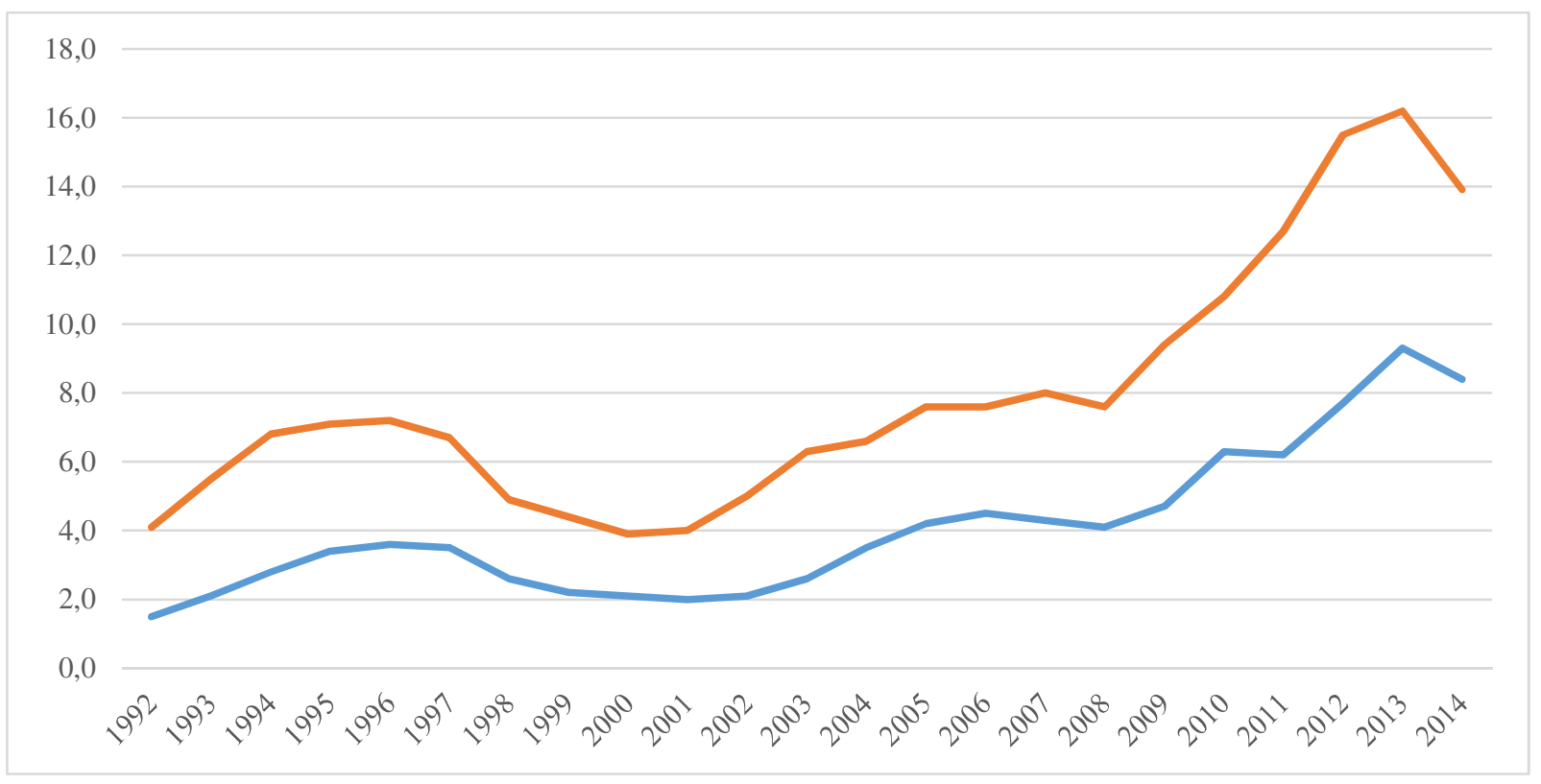

In addition to unemployment, wages are also a key variable for determining the dynamics in the labour market. In terms of wage policy, one of the most commonly used instruments is minimum wage policy. According to the European Commission, the rise in the minimum wage worsens the level of long-term unemployment, especially of low-skilled workers. By 2019, the national minimum wage is expected to increase to 600 euros, which could exacerbate unemployment, including long-term unemployment ${ }^{5}$.

\section{Education and Skills}

One of the greatest challenges to the competitiveness of the Portuguese economy is the low level of skills and education of the resident population ${ }^{6}$. An uneducated population is less productive, less capable of adjusting to technical change, and less empowered.

According to the census of 2011, Portugal still counted half a million people who could not read or write, i.e. about $5 \%$ of the population. In the first quarter of $2016,45 \%$ of the population between the ages of 55 and 64 had less than six years of formal schooling, and less than $15 \%$ of them held an undergraduate degree (Table 2years of formal schooling.

). Although low levels of formal education especially affect people over the age of 45 , they are still observed in younger generations. Indeed, it is noteworthy that more than

\footnotetext{
${ }^{5}$ CEnTENO, M., DUARTE, C., \& NOVO, Á. A. - The Impact of the Minimum Wage on Low-wage Earners.

${ }^{6}$ GOVERNO DE PORTUGAL - Plano Nacional de Reformas
} 
$2.5 \%$ of the population between the ages of 25 and 34 had not even completed, in 2016, six years of formal schooling.

Table 2: Resident population by age group and highest level of education successfully completed $\left(1^{\text {st }}\right.$ quarter of 2016). Source: INE.

\begin{tabular}{|c|c|c|c|c|c|}
\hline Formal Schooling & $25-34$ & $35-44$ & $45-54$ & $55-64$ & $65+$ \\
\hline None & $0.81 \%$ & $1.54 \%$ & $2.62 \%$ & $4.44 \%$ & $26.86 \%$ \\
\hline 4 years & $1.74 \%$ & $5.05 \%$ & $19.08 \%$ & $41.72 \%$ & $49.62 \%$ \\
\hline 6 years & $7.89 \%$ & $14.57 \%$ & $19.91 \%$ & $11.26 \%$ & $3.94 \%$ \\
\hline 9 years & $21.52 \%$ & $21.95 \%$ & $21.01 \%$ & $17.91 \%$ & $9.51 \%$ \\
\hline High-School & $34.34 \%$ & $26.68 \%$ & $19.02 \%$ & $11.99 \%$ & $4.26 \%$ \\
\hline Higher Education & $33.72 \%$ & $30.20 \%$ & $18.36 \%$ & $12.68 \%$ & $5.80 \%$ \\
\hline
\end{tabular}

Still, it is important to notice the great improvement in the last few years in the levels of education of the Portuguese population. Indeed, there has been a significant reduction in the proportion of people who have only completed four years of schooling. There has also been an increase in the share of people finishing high-school or acquiring an undergraduate degree. If in 2011 about $67 \%$ of the population between the ages of 25 and 65 had not even finished high-school, in 2016 this figure had dropped to 55\% (Table 3).

Table 3: Proportion of resident population between the ages of 25 and 64 per highest level of education completed ( $1^{\text {st }}$ quarter). Source: INE

\begin{tabular}{|c|c|c|}
\hline Formal Schooling & $\mathbf{2 0 1 1}$ & $\mathbf{2 0 1 6}$ \\
\hline None & $4.76 \%$ & $2.37 \%$ \\
\hline 4 years & $24.81 \%$ & $16.97 \%$ \\
\hline 6 years & $16.56 \%$ & $13.79 \%$ \\
\hline 9 years & $20.47 \%$ & $20.63 \%$ \\
\hline High-School & $16.55 \%$ & $22.70 \%$ \\
\hline Higher Education & $16.85 \%$ & $23.54 \%$ \\
\hline
\end{tabular}

Despite these improvements, the share of people completing only 6 years of schooling has suffered a very slight reduction, remaining high, and that completing only 9 years of schooling remains stable and high. Also, the share of people between the ages of 25 and 64 with an undergraduate degree is the fifth lowest among OECD countries, and the sixth lowest if considering only the population between the ages of 25 and $34^{7}$. Besides this, as of 2016, only $32 \%$ of the population aged between 30 and 34 has a higher education diploma, which, although an increase since 2010, when the share was

\footnotetext{
${ }^{7}$ OECD - Education at a Glance
} 
merely $24 \%$, is still quite below the $40 \%$ goal for 2020 as featured in the European Semester.

The need to develop the skills and further the education of the Portuguese population is clearly a challenge for 2030, and is felt across all levels of education. It is also necessary to promote the certification of skills already acquired. Although certification does not create skills directly, it promotes transparency, makes quality control easier and motivates people. If the path followed in the last five years is continued, by 2030 Portugal will be closer to the other European countries with respect to education and skills. However, it should not be expected that all these issues will be completely resolved in such a short period of time.

\section{Energy and Natural Resources}

\section{Portugal, climate change, and sources of energy}

One cannot discuss energy issues without referring to climate change. Climate change has been linked, essentially, to the increased greenhouse gas emissions, which, in turn, is a product of energy production and consumption. Thus, these two issues should be addressed simultaneously: to fight climate change requires changes in the way energy is produced and consumed.

The fight against climate change generates important challenges. Following a growing concern with the negative impacts of climate change, the countries that ratified the United Nations Framework for Climate Change agreed to curb greenhouse gas emissions in what came to be known as the Paris agreement. One of the goals of the agreement is to keep the increase in global average temperature to $2^{\circ} \mathrm{C}$ above preindustrial levels. Every signatory country has agreed to implement measures conducing to that goal and to report its emissions. The most developed countries will also subsidize developing countries with 100 billion euros per year, from 2020 to 2025 . Nevertheless, not every treaty provision has the force of law.

In this context, Portugal accepted to eradicate the use of fossil energy before 2050. In the transportation sector, in 2030, that reduction should already amount to $26 \%$. Meeting the objectives depends on a far-reaching conversion in energy consumption and production, which has been happening since the beginning of the last decade through large investments in renewable energy. Indeed, in 2000, 30,3\% of the total amount of electric power was produced from a renewable source, while in 2014 that 
proportion had risen to about $62,4 \%$ (Figure 5). Despite some variability, the proportion of energy produced out of renewable sources has been increasing since 2005 in Portugal.

Figure 5: Proportion of power production from renewable sources. Source: Pordata.

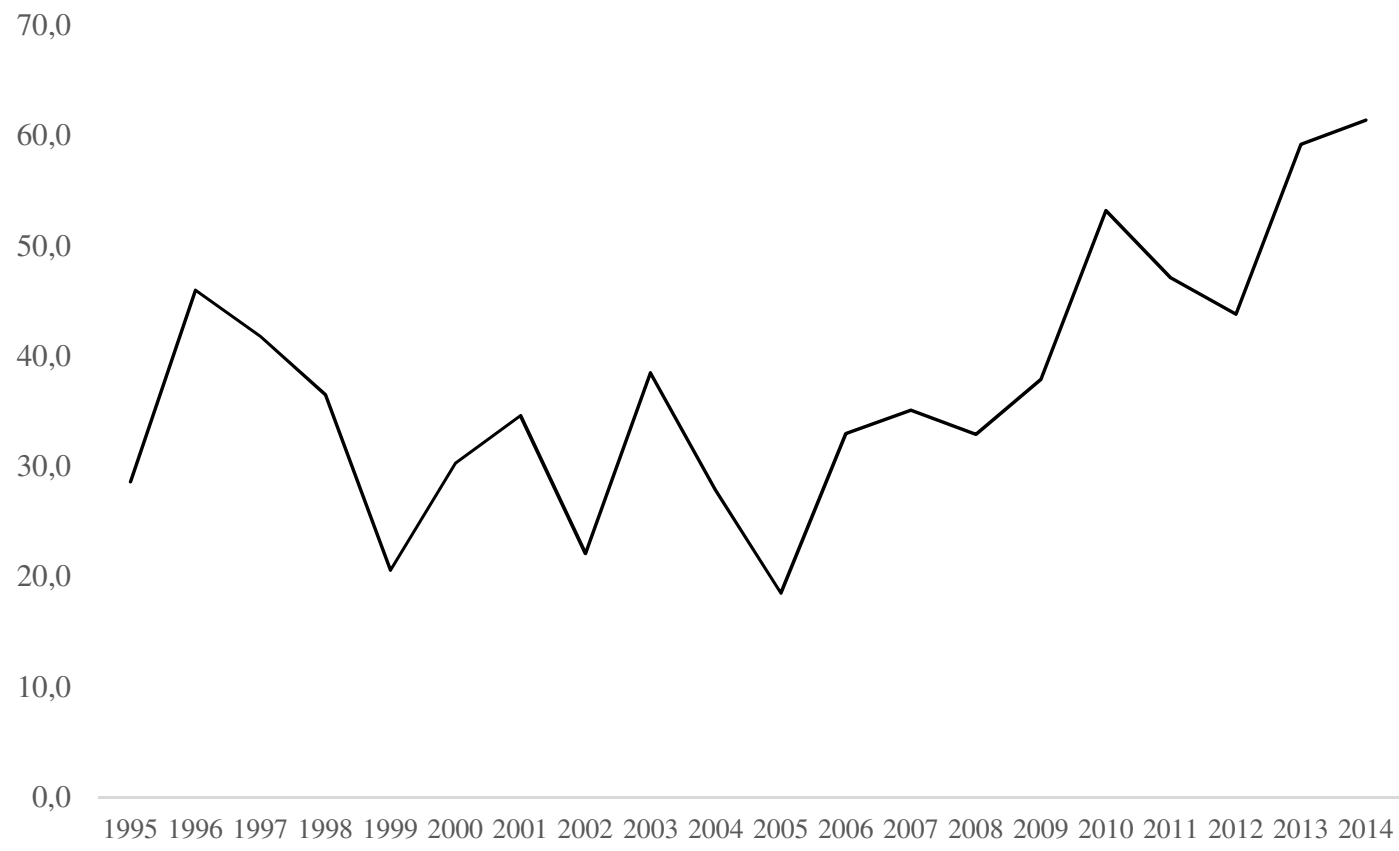

Hydropower represents a significant portion of the renewable energy produced in Portugal. This implies that current energy production is dependent on the availability of water (Figure 6). Such dependence may be cause for concern insofar as there are forecasts indicating an increased prevalence of droughts due to climate change. Indeed, water shortages may become much more common in the future ${ }^{8}$ (Vasconcelos (ed.), 2012). Also, such shortages will not homogenously affect the entire Portuguese territory. As highlighted by the reports Alterações Climáticas em Portugal: Cenários, Impactos e Medidas de Adaptação (SIAM II), climate simulations indicate that raining will increase in the North of Portugal, while it is expected to decrease in the south. Moreover, raining may become more concentrated in Winter months, thus increasing the risk of floods. This changes pose challenges in what concerns the management of waterdams, and thus, to capacity for energy production.

These challenges notwithstanding, Figure 6 shows that the proportion of hydric energy has been declining as a result of investment in wind power plants. Today, the amount of electric power generated from wind is almost the same as that generated from

\footnotetext{
${ }^{8}$ VASCONCELOS, Á. (Ed.) - Global Trends 2030
} 
water. It is expectable that the relative importance of wind power will grow, spurred by technological advances especially power-storage capacity, as well as by the extension of the Exclusive Economic Zone of Portugal. This latter circumstance will allow the creation of offshore power farms, and thus an increase to the capacity for wind power production.

Figure 6: Total power production from renewable sources (GWh). Source: Pordata

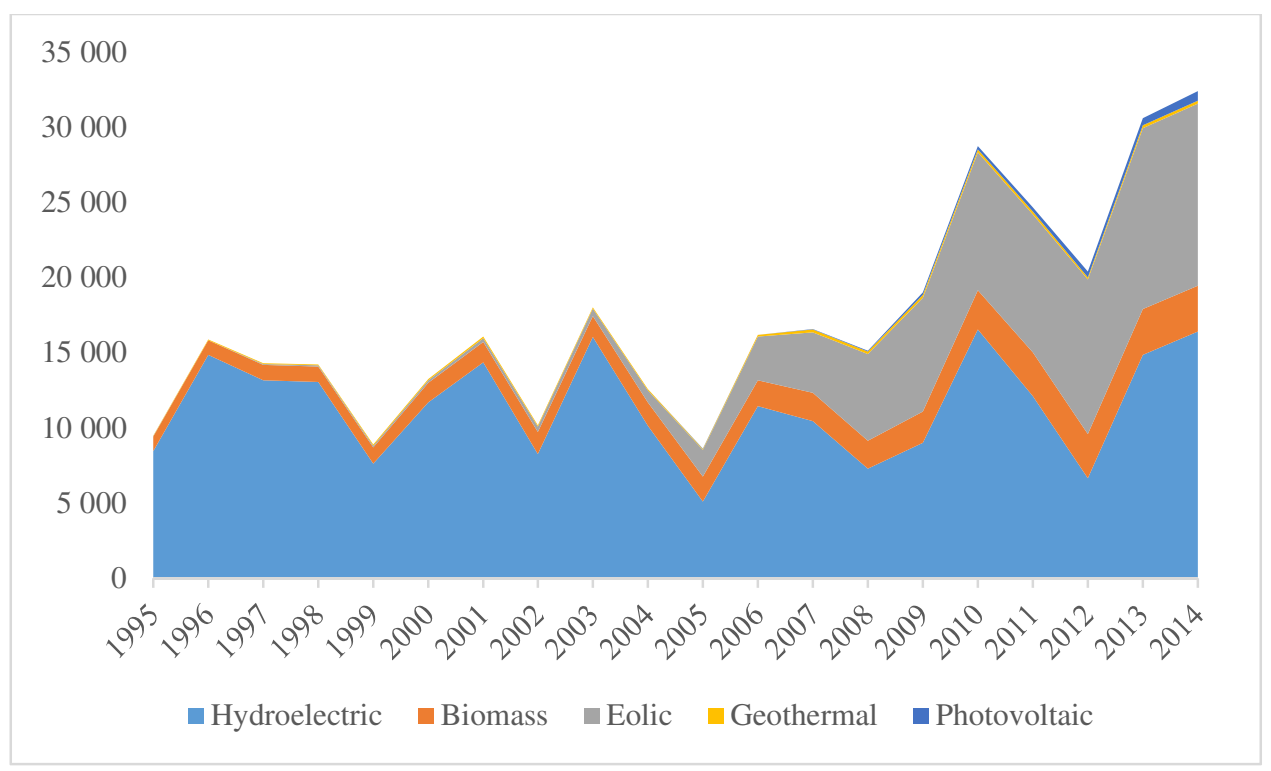

\section{Portugal and the energy policies of the European Union}

Portuguese energy policy is conditioned by European Union (EU) strategies, objectives and directives. For the coming years, EU energy policy will focus on greenhouse gas reduction, on the competitiveness of the energy sector, and on the improvement of energy security.

Regarding emissions, following the Paris agreement, the EU's objective is to reduce by $40 \%$ greenhouse gas emissions until 2030. That goal should be accomplished by both changing primary energy sources and by efficiency improvements. Thus, in 2030, $27 \%$ of the total energy consumed is expected to have been produced out of renewable sources, and energy efficiency should have been improved by $27 \%$.

The most common indicator of efficiency in the consumption of energy is energy intensity. It measures the average quantity of energy used to produce a unit of GDP. Both Portugal and the EU as a whole have been improving their efficiency in recent years. It is, however, necessary to note that Portugal has always been less efficient than the EU (Figure 7). 
Figure 7: Energy intensity (kg of oil by $1000 €$ of value added). Source: Pordata.

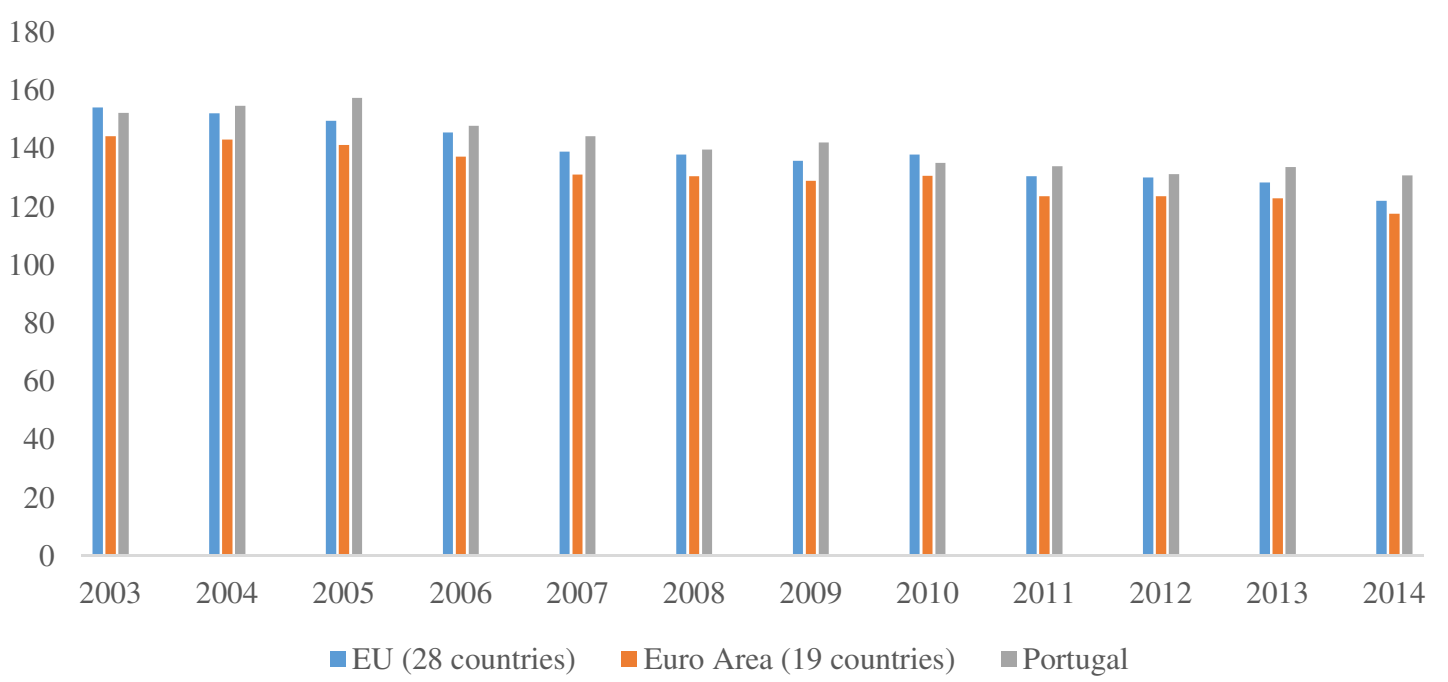

In order to improve Europe's energy competitiveness, the strategy adopted involves the exploitation of economies of scale through the establishment of a unified European market for energy power. One of the main instruments to implement this strategy is the (intended) construction of infrastructures for transporting power across EU countries.

Finally, EU energy security appears as one of the main challenges for the coming years. Indeed, EU countries are dependent on energy imports from foreign, unstable, countries. The exploitation of shale gas in the United States may create an alternative to Russian or Algerian natural gas. In this context, the privileged geographical location of Portugal, as well as the infrastructures of the port of Sines, may turn Portugal into Europe's entry point for foreign gas.

However, changing the suppliers does not address the challenge of overcoming the EU's energy dependency from external countries, a problem that is especially relevant for Portugal. Indeed, Portugal imports $79 \%$ of its energy resources, while the EU average is about $54 \%^{9}$.

\section{Energy prices in Portugal}

The main determinants of energy price in Portugal for the coming years will be the price of oil, the evolution of energy efficiency at the level of production, and the evolution of the tariff deficit.

The tariff deficit refers to the difference between the amount paid by consumers and the real cost of production and transport of the power consumed. In 2006, Portuguese

\footnotetext{
${ }^{9}$ Source: EUROSTAT
} 
public authorities opted to not reflect total costs on prices. An important part of the difference between costs and prices is the result of guarantees by the State to the company Energias de Portugal (EDP) on the latter's selling price for power produced from endogenous resources. These prices have systematically been above the wholesale market price of power, meaning that this scheme has generated losses to EDP. These losses are debts owed by consumers to EDP, accruing at compound interest.

In 2015, the tariff deficit amounted to 1.5 billion euros. It is expected that this deficit will be payed off before 2022. Thus, increases in energy prices beyond variations in the cost of production and transportation are expected.

\section{Income Inequality and Poverty}

\section{Income Inequality}

When discussing inequality, it is important to make clear what kind of inequality is under scrutiny.

On the one hand, we might discuss inequality in the distribution of income, as opposed to inequality in the distribution of wealth. Indeed, a family unit may rank differently in the two distributions: a family with high income may not have accumulated any wealth, and vice-versa.

On the other hand, even when discussing inequality in the distribution of income, we might focus on inequality in the distribution of pecuniary income, or include other sources of income, such as those resulting from transfers in kind between members of a family unit. According to RODRIGUES, C. F., FIGUEIRAS, R., \& JUNQUEIRA, V. Desigualdade Económica em Portugal, p. 43, in Portugal total income is more equally distributed than pecuniary income. The authors show that if non-pecuniary sources of income are taken into account, there are important changes in the relative position of most family units: more than half shifts at least one decile, and $11 \%$ more than one.

Instead of enlarging the domain of analysis, we might also reduce it, and discuss the distribution of particular kinds of income, such as the pecuniary income due to work (salaries and wages). These tend to be more unequally distributed than total income. Finally, we might discuss the distribution of net or gross income, inequality being greater for the distribution of the latter than for that of the former. 
To get acquainted with the order of magnitude of family income in Portugal, we will look at annual, net pecuniary income of Portuguese family units. When we study this indicator, we observe that, in 2015, half the family units made less than $8435 €$ per adult-equivalent ${ }^{10}$, or about $700 €$ per person per month, $90 \%$ of family units made more than $3629 €$ per adult-equivalent, or $300 €$ per person per month, whereas $99 \%$ of family units made less than $37934 €$ per adult-equivalent, or $2700 €$ per-person per month (Table 4). To put these figures into an example, a family unit with two working adults, each earning more than $1735 €$ net per month, for 14 months in a year (as usual in Portugal), would earn more than $99 \%$ of all family units in Portugal.

Table 4: Quantiles for annual, net pecuniary income $(€)$ of family units, per adult-equivalent. Source: EUROSTAT

\begin{tabular}{|c|c|c|c|c|}
\hline Quantile & $\mathbf{1 9 9 5}$ & $\mathbf{2 0 0 5}$ & $\mathbf{2 0 1 0}$ & $\mathbf{2 0 1 5}$ \\
\hline $\mathbf{1 \%}$ & $:$ & 1,187 & 1,912 & 1,196 \\
\hline $\mathbf{1 0 \%}$ & 1,761 & 3,236 & 4,181 & 3,629 \\
\hline $\mathbf{2 5 \%}$ & 2,714 & 4,871 & 5,976 & 5,705 \\
\hline $\mathbf{5 0 \%}$ & 4,337 & 7,195 & 8,678 & 8,435 \\
\hline $\mathbf{7 5 \%}$ & 6,543 & 10,745 & 12,631 & 12,134 \\
\hline $\mathbf{9 0 \%}$ & 9,993 & 17,733 & 18,975 & 17,582 \\
\hline $\mathbf{9 9 \%}$ & $:$ & 43,170 & 38,794 & 37,934 \\
\hline
\end{tabular}

If compared with other European countries, Portugal suffers from particularly high levels of inequality in the distribution of income ${ }^{11}$. Indeed, the share of net, pecuniary income going to the $20 \%$ most highly remunerated family units was, in 2014 , six times greater than the share going to the $20 \%$ of units at the bottom (Table 5). In other EU countries, it is only about five times. The values of the Gini coefficient lead to similar conclusions $^{12}$.

Table 5: Ratio between the share of net, pecuniary income going to the $20 \%$ most highly remunerated family units and that going to the $20 \%$ least remunerated units. Source: EUROSTAT

\begin{tabular}{|c|c|c|c|}
\hline & $\mathbf{1 9 9 5}$ & $\mathbf{2 0 0 5}$ & $\mathbf{2 0 1 4}$ \\
\hline European Union (15) & 5.1 & 4.8 & 5.2 \\
\hline Portugal & 7.4 & 7.0 & 6.2 \\
\hline
\end{tabular}

\footnotetext{
${ }^{10}$ In order to account for economies of scale in larger family units, the notion of adult-equivalent has been introduced. For EUROSTAT, the first adult with at least 14 years of age counts as one adult-equivalent, and all the others as 0.5 adult-equivalent. Children with less than 14 years of age count as 0.3 adultequivalent. Thus, a family unit with two adults count as 1.5 adult-equivalent, whereas a family unit with two adults and two children counts as 2.1 adult-equivalent.

${ }^{11}$ RODRIGUES, C. F., FIGUEIRAS, R., \& JUNQUEIRA, V. - Desigualdade Económica em Portugal, pp. 45-51.

${ }^{12}$ The Gini coefficient varies between 0 , if all family-units earn the same income per adult-equivalent, and 100, if one family unit earns the entire income distributed in the community. At present, the Gini coefficient for the World is over 60 .
} 
Table 6: Gini Coefficient. Source: EUROSTAT

\begin{tabular}{|c|c|c|c|}
\hline & $\mathbf{1 9 9 5}$ & $\mathbf{2 0 0 5}$ & $\mathbf{2 0 1 4}$ \\
\hline European Union (15) & 31 & 29.9 & 30.9 \\
\hline Euro-Zone (19) & $:$ & 29.4 & 31.0 \\
\hline Portugal & 37 & 38.1 & 34.5 \\
\hline
\end{tabular}

In spite of these differences, both indicators show a decrease in income inequality for Portugal during the last few years. Indeed, since the late 1960s, there has been a trend of lowering income inequality in Portugal, in great part due to an increase in the share of income going to the poorest family units ${ }^{13}$. This share has, however, stopped growing in the last few years. At the same time, there has been a reduction, since 2005, in the share of net income distributed to the $1 \%$ at the top. It is also noteworthy that there has not been any decrease in the share of total income going to family units close the median, quite the opposite (Table 7).

Table 7: Share of total net income per quantile. Source: EUROSTAT

\begin{tabular}{|c|c|c|c|c|}
\hline Quantile & $\mathbf{1 9 9 5}$ & $\mathbf{2 0 0 5}$ & $\mathbf{2 0 1 0}$ & $\mathbf{2 0 1 5}$ \\
\hline $\mathbf{1 \%}$ & $:$ & 0.1 & 0.1 & 0.1 \\
\hline $\mathbf{1 0 \%}$ & 2 & 2.5 & 2.9 & 2.5 \\
\hline $\mathbf{2 5 \%}$ & 8 & 9.0 & 10.2 & 9.6 \\
\hline $\mathbf{5 0 \%}$ & 17 & 16.0 & 17.1 & 17.6 \\
\hline $\mathbf{7 5 \%}$ & 25 & 23.2 & 24.9 & 25.1 \\
\hline $\mathbf{9 0 \%}$ & 16 & 15.4 & 15.0 & 15.2 \\
\hline $\mathbf{9 9 \%}$ & $:$ & 6.4 & 5.1 & 5.2 \\
\hline
\end{tabular}

\section{Poverty}

The index of material deprivation is one of the indicators used to quantify both the number of family units suffering poverty, as well as the intensity of the poverty they face. EUROSTAT takes a family unit to be materially deprived if they fail on at least three of the following items ${ }^{14}$ :

1. Ability to deal with an unexpected financial expense, without taking out a loan.

2. Ability to afford a week's annual holiday away from home for the entire family unit.

3. Ability to meet all expenses without arrears.

\footnotetext{
${ }^{13}$ RODRIGUES, C. F., FIGUEIRAS, R., \& JUNQUEIRA, V. - Desigualdade Económica em Portugal, pp. 61ff.

${ }^{14}$ Adapted from the original list developed by the EUROSTAT.
} 
4. Ability to afford a meal with meat, chicken, fish or vegetarian equivalent every second day.

5. Ability to keep the home adequately warm.

6. Availability of a washing machine.

7. Availability of a colour TV.

8. Availability of a telephone.

9. Availability of a personal car.

According to this indicator, Portugal has a proportion of family units suffering from material deprivation that is much higher than its European counterparts. As in the rest of Europe, the number of deprived family units increased between 2005 and 2014, when it represented more than a quarter of Portuguese family units. However, in 2015 there was a significant decrease in this indicator, bringing it back to the level of 2005 (Table 8).

Table 8: Proportion of family units suffering from material deprivation. Source: EUROSTAT

\begin{tabular}{|c|c|c|c|c|}
\hline & $\mathbf{2 0 0 5}$ & $\mathbf{2 0 1 0}$ & $\mathbf{2 0 1 4}$ & $\mathbf{2 0 1 5}$ \\
\hline European Union (28) & $:$ & 17.9 & 18.5 & $:$ \\
\hline Euro Zone (19) & 14.3 & 14.4 & 16.4 & $:$ \\
\hline Portugal & 21.2 & 22.5 & 25.7 & 21.6 \\
\hline
\end{tabular}

\section{Conclusion}

After this short survey on the past and present of the Portuguese economy with a view to its future(s), it is plausible to assert that, in 2030, Portugal will be richer than today, but comparatively poorer. Its residents will live longer, but will have to face the challenge of transferring income from a smaller working to a larger retired population. Those residents will be better educated than today, hence more empowered, demanding and capable of taking part in the economic and technological transformations the future will bring. However, they will remain less qualified than their counterparts in other countries and it is impossible to know whether the market for their services will already have left behind the two-digit rates of unemployment we observe today. It is also impossible to predict whether the Portuguese State will be financially capable of responding to the aspirations that a more empowered population will articulate in the public sphere. Portugal will be a greener economy, but with high energy costs, and will be facing its very own challenges brought by climate change. Income in Portugal is 
likely to no longer be more unequally distributed than in its European counterparts, but because Europe will face greater inequality.

\section{References}

ALEXANDRE, F., AGUIAR-CONRARIA, L., \& BAÇÃO, P. Crise e Castigo: os Desequilíbrios e o Resgate da Economia Portuguesa. Lisboa: Fundação Francisco Manuel dos Santos, 2016.

CENTENO, M., DUARTE, C., \& NOVO, Á. A. - The Impact of the Minimum wage on Low-wage Earners. Economic Bulletin and Financial Stability Report Articles, 2011.

GOVERNO DE PORTUGAL - Plano Nacional de Reformas, 2016.

IMF - Country Report 13/19, 2013.

OECD - Education at a Glance, 2015.

RODRIGUES, C. F., FIGUEIRAS, R., \& JUNQUEIRA, V. - Desigualdade Económica em Portugal. Lisboa: Aletheia, 2012.

SANTOS, F. D., \& MIRANDA, P. (Eds.) - Alterações Climáticas em Portugal: Cenários, Impactos e Medidas de Adaptação (Projeto SIAM II). Lisboa: Gradiva, 2006.

VASCONCELOS, Á. (Ed.) - Global Trends 2030: Citizens in an Interconnected and Polycentric World. Paris: Institute for Security Studies of the European Union, 2012.

Article received on December 20, 2016 I Accepted December 30, 2016 